\title{
Gegeneraliseerde kostenrelaties in de detailhandel
}

\section{Inleiding}

In deze studie gaan we op zoek naar een relatie tussen enerzijds gemiddelde arbeid of gemiddelde oppervlakte en anderzijds gemiddelde omzet per vestiging voor vele verschillende winkeltypen in de detailhandel. We vinden inderdaad een relatie waarbij verschillende eigenschappen van de winkeltypen een belangrijke rol spelen. Deze eigenschappen zijn: gemiddelde loonvoet per manjaar, gemiddelde huurwaarde per $\mathrm{m}^{2}$ bedrijfsvloeroppervlakte, gemiddelde procentuele verkoopvloeroppervlakte, gemiddelde procentuele ondernemersarbeid en het feit of het winkeltype voedings- en genotmiddelen verkoopt of duurzame en overige goederen. De gevonden relaties lijken veelbelovend, aangezien hun specificatie plausibel is in het licht van theorievorming op het niveau van individuele vestigingen per winkeltype, hun statistische verklaring zeer hoog is en de fouten van de geschatte coëfficiënten systematisch zeer laag zijn.

Met behulp van de gevonden relaties zijn we dus in staat verschillen in gemiddelde arbeidsproduktiviteit en gemiddelde vloerproduktiviteit tussen winkeltypen te verklaren. Voorts zijn er nog verdere toepassingen voor onderzoek denkbaar van de hier gepresenteerde relaties. Aan deze toepassingen is een aparte paragraaf gewijd (paragraaf 5). De in deze studie gerapporteerde schattingen zijn gemaakt met data van het E.I.M.-Bedrijfssignaleringssysteem, een informatie-uitwisselingssysteem voor ondernemers en accountants in het midden- en kleinbedrijf. De hier gebruikte gegevens hebben betrekking op de fiscale jaarstukken van 1981, die onder geheimhouding werden verstrekt door accountants, werkzaam in het midden- en kleinbedrijf (veelal A.A.-consulenten). Deze verstrekking heeft twee oogmerken. Ten eerste het verschaffen van branchegerichte informatie aan organisaties en bedrijfsadviseurs op het terrein van het midden- en kleinbedrijf en ten tweede het verrichten van theorievormend, modelmatig onderzoek.

\section{Kostenrelaties per winkeltype}

Op het Economisch Instituut voor het Midden- en Kleinbedrijf (E.I.M.) zijn uitgebreide kwantitatieve studies verricht op het gebied van arbeidsproduktiviteit in de detailhandel. Deze studies zijn veelal verricht in samenwerking met het Econometrisch Instituut van de Erasmus Universiteit 
Rotterdam.

Zij hebben aangetoond dat er een lineaire niet-homogene relatie bestaat per winkeltype tussen enerzijds het volume van arbeid en anderzijds de waarde van de jaarlijkse omzet ${ }^{1}$ :

$$
\mathrm{L}=\alpha_{0}+\alpha_{1} \mathrm{Q} \text { met } \alpha_{0}>0 \text { en } x_{1}>0,
$$

waarde: $\mathrm{L}$ : aantal werkzame personen in full-time equivalenten per vestiging;

Q : waarde van de jaarlijkse omzet per vestiging;

$x_{0}$ : drempelcoëfficiënt;

$\alpha_{1}$ : hoekcoëfficiënt.

Vergelijking (1) behoeft enige verduidelijking. Een winkeltype is gedefinieerd als een groep vestigingen met een zekere homogeniteit betreffende assortiment, bedieningswijze (zelfbediening), mate van eigen produktie (ambacht) en organisatiewijze (zelfstandig of filiaal). De waarde van de drempelcoëfficiënt wordt in verband gebracht met de minimale hoeveelheid arbeid die altijd in de vestiging aanwezig moet zijn; deze hoeveelheid wordt geacht een functie te zijn van de jaarlijkse openingstijd en het aantal onafhankelijk bemande afdelingen in de vestiging. $\mathrm{Bij}$ de meeste detailhandelsvestigingen is dit aantal één en wordt deze ene 'afdeling' bemand door de eigenaar/filiaalchef of diens (part-time) plaatsvervanger (veelal een familielid). Bij grotere detailhandelsvestigingen kan soms meer dan één onafhankelijke afdeling onderscheiden worden (cassière in een zelfbedieningsvestiging of een slagersbediende in een slagerij in een supermarkt).

Winkeltypen worden dusdanig gedefinieerd dat het aantal onafhankelijk bemande afdelingen van alle vestigingen gelijk is. De hoekcoëfficiënt wordt ook wel schaalgecorrigeerde arbeidsintensiteit genoemd. Deze naamgeving wordt duidelijk na herschrijving van vergelijking (1):

$$
\mathrm{L} / \mathrm{Q}=x_{1}+\alpha_{0} / \mathrm{Q},
$$

waarbij: L/Q : de arbeidsintensiteit (= de inverse van de arbeidsproduktiviteit),

$\alpha_{1} \quad$ : het schaal (= omzet) onafhankelijke deel hiervan en

$\alpha_{0} / Q$ : het schaal afhankelijke deel.

Vergelijkingen (1) en (2) worden grafisch weergegeven in figuren 1 en 2. 


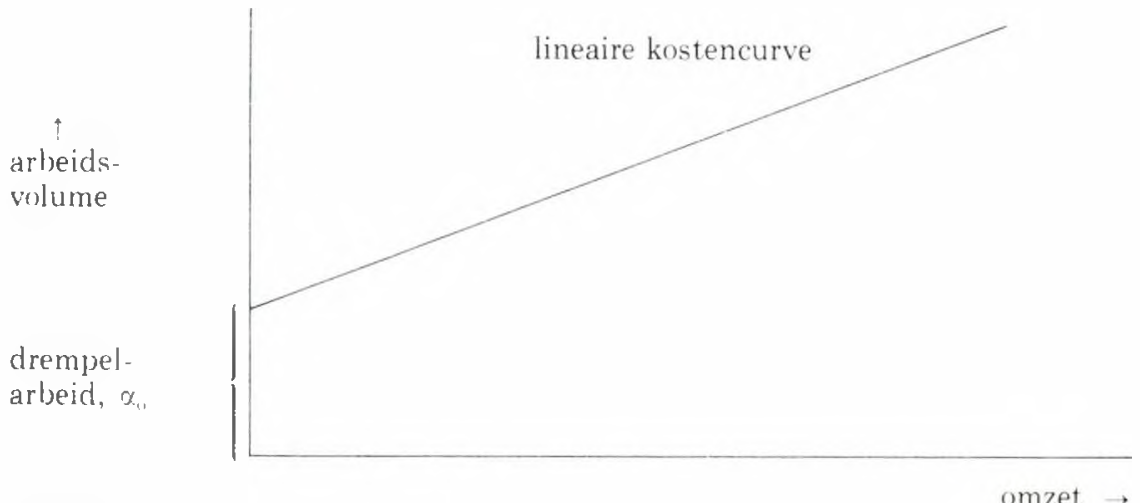

figuur 2

omzet $\rightarrow$

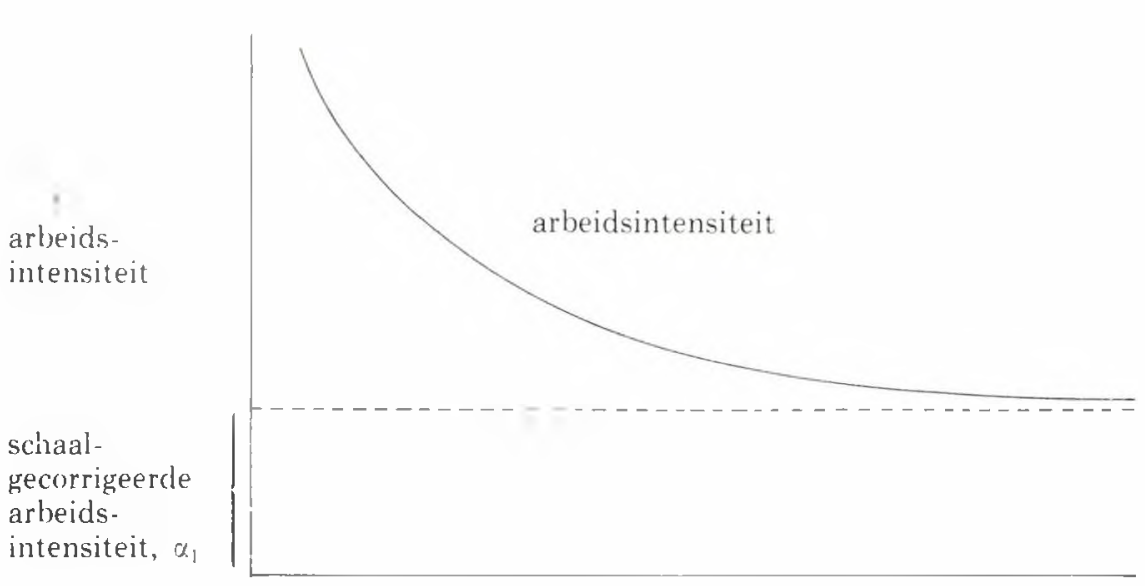

omzet -

Vergelijking (2) leert ons het volgende met betrekking tot de invloed van de schaal op de arbeidsintensiteit, indien er inderdaad sprake is van drempelarbeid, ofwel indien inderdaad $x_{0}>0$. In dit geval daalt de arbeidsintensiteit met toenemende schaal. Deze daling wordt echter steeds minder bij toenemende schaal. Het feit dat arbeidsintensiteit daalt met toenemende schaal van de vestiging wordt vaak in detailhandelsstudies aangetroffen ${ }^{2}$. Uitgebreide studies zijn verricht om verschillen in schaalgecorrigeerde arbeidsintensiteit per vestiging voor een bepaald winkeltype te verklaren ${ }^{3}$. Belangrijke verklarende variabelen blijken te zijn: loonvoet per gewerkt uur, assortiment, bedieningswijze en toeleveringswijze. Interessant is ook de toepassing van vergelijking (1) bij het ontwerpen van een methodiek voor de verklaring/prognose van de ontwikkeling van de gemiddelde arbeidsproduktiviteit in een bepaalde detailhandelsbranche ${ }^{4}$.

Een laatste opmerking ter verduidelijking van vergelijking (1) is de vaststelling dat de relatie tussen arbeid en omzet wordt beschouwd zonder de invloed van kapitaal erbij te betrekken. Deze werkwijze vloeit voort uit de tamelijk nauwgezette definitie van een winkeltype: als er substitutiemoge- 
lijkheden zouden zijn tussen arbeid en kapitaal (in de detailhandel vaak geassocieerd met vloeroppervlakte), dan doen deze zich voor tussen winkeltypen en niet binnen een winkeltype.

Niet alleen op het gebied van arbeidsproduktiviteit zijn studies verricht, maar ook op het gebied van vloerproduktiviteit. Deze studies hebben aangetoond dat er per winkeltype ook tussen enerzijds bedrijfsvloeroppervlakte en anderzijds de waarde van de jaarlijkse omzet een lineaire niethomogene relatie bestaat.

Het gebruik van de vloeroppervlaktevergelijking heeft als nadelen dat de theoretische onderbouw minder stevig is dan in het geval van de arbeidsvergelijking (1) en dat er in empirische studies een veel groter onverklaard deel overblijft dan in het geval van de arbeidsvergelijking. Er zijn dan ook studies verricht met een andere filosofie over de relatie tussen oppervlakte en omzet ${ }^{5}$. Schattingen van de drempelcoëfficiënt in de vloeroppervlaktevergelijking voor winkeltypen met één onafhankelijke bemande afdeling, hebben vaak een getal van $\pm 40 \mathrm{~m}^{2}$ opgeleverd. Dit lijkt een redelijke minimale oppervlakte voor één onafhankelijk bemande afdeling.

\section{Gegeneraliseerde kostenrelaties in de detailhandel}

In deze studie zijn we niet geïnteresseerd in de relatie tussen enerzijds arbeid of oppervlakte en anderzijds omzet per vestiging, maar in de relatie tussen enerzijds gemiddelde arbeid of gemiddelde oppervlakte en anderzijds gemiddelde omzet per vestiging voor vele verschillende winkeltypen in de detailhandel.

Data van de E.I.M.-Bedrijfssignalering, een informatie-uitwisselingssysteem voor ondernemers en accountants in het midden- en kleinbedrijf, worden gebruikt voor empirische analyses. De exploitatiegegevens van branches/ bedrijfsgroepen over 1981 zijn gebruikt.

De beschouwde winkeltypen zijn opgesomd in Appendix A.

We zien dat er grote verschillen zijn onder deze 49 winkeltypen. Er zijn er uit de sector van de voedings- en genotmiddelen (bijvoorbeeld slagers, banketwinkels, viszaken), maar ook uit de sector van de duurzame en overige goederen (bijvoorbeeld drogisterijen, herenkleding, ijzerwaren). Er zijn er met een grote mate van zelfbediening (bijvoorbeeld supermarkten), maar ook met een grote mate van ambacht (bijvoorbeeld fietsenwinkels). Door deze verscheidenheid aan winkeltypen kunnen we pretenderen dat de uitspraken, die het resultaat zijn van onze analyses, geldig zijn voor het midden- en kleinbedrijf in de detailhandel in het algemeen.

De relaties tussen enerzijds gemiddelde arbeid of gemiddelde oppervlakte en anderzijds gemiddelde omzet per vestiging voor winkeltypen in de detailhandel noemen we gegeneraliseerde kostenrelaties. Onze bevindingen met betrekking tot schattingen met deze gegeneraliseerde kostenrelaties zullen wij hieronder samenvatten.

Voor een technische afleiding van de gegeneraliseerde kostenrelatie en de precieze schattingsresultaten verwijzen we naar Appendix B. Wij formuleren 11 stellingen, ten einde de verslaglegging van onze bevindingen te stroomlijnen. 
Wanneer wij veronderstellen dat vestigingen van een bepaald winkeltype in het algemeen één onafhankelijk bemande afdeling hebben, dan lijkt $1 \frac{1}{4}$ manjaar een redelijk uitgangspunt voor de drempelarbeid. In Nederland is de wettelijke maximale openingstijd ongeveer 2.500 uur per jaar, ofwel 1 manjaar. Voor de drempeloppervlakte is vaak een empirische waarde van $40 \mathrm{~m}^{2}$ gevonden. Met betrekking tot de door ons beschouwde winkeltypen kunnen we niet zonder meer veronderstellen dat zij één onafhankelijk bemande afdeling hebben.

Voor de volgende vijf rekengroepen is deze veronderstelling ons inziens onterecht: de twee rekengroepen van supermarkten met ambachtelijke slagerij en de grootste rekengroepen van supermarkten zonder ambachtelijke slagerij, woninginrichting die voornamelijk meubels verkopen en gemengde woninginrichting. Met betrekking tot deze rekengroepen veronderstellen we een hogere drempelarbeid en drempeloppervlakte dan voor de overige rekengroepen. Voor deze additionele drempelarbeid en drempeloppervlakte kiezen we geen a priori waarden, aangezien de vijf desbetreffende rekengroepen onderling nogal verschillend zijn. Wij formuleren nu de volgende vier stellingen. De tussen haakjes geplaatste coëfficiënten hebben betrekking op de in Appendix B gebruikte notatie.

Stelling 1: drempelarbeid voor winkeltypen die in het algemeen één onafhankelijk bemande afdeling hebben, is gelijk aan $1 \frac{1}{1}$ manjaar $\left(\alpha_{0}=1 \frac{1}{1}\right)$.

Stelling 2: drempelarbeid voor winkeltypen die in het algemeen meer dan één onafhankelijk bemande afdeling hebben, is groter dan $1 \frac{1}{4}$ manjaar $\left(\alpha_{01}>0\right)$.

Stelling 3: drempeloppervlakte voor winkeltypen die in het algemeen één onafhankelijk bemande afdeling hebben, is gelijk aan $40 \mathrm{~m}^{2}\left(\beta_{\mathrm{o}}=40\right)$.

Stelling 4: drempeloppervlakte voor winkeltypen die in het algemeen meer dan één onafhankelijk bemande afdeling hebben, is groter dan $40 \mathrm{~m}^{2}$ $\left(\beta_{\mathrm{ol}}>0\right)$.

Het is duidelijk dat er enorme verschillen zijn in de schaalgecorrigeerde arbeidsintensiteiten tussen de winkeltypen en de schaalgecorrigeerde vloerintensiteiten tussen de winkeltypen. We zullen proberen wetmatigheden te veronderstellen die deze intensiteiten beïnvloeden. Voorts zullen we proberen bij deze wetmatigheden variabelen aan te geven. Deze wetmatigheden zullen weer gepresenteerd worden in de vorm van stellingen.

Stelling 5: schaalgecorrigeerde arbeidsintensiteit neemt af naarmate de loonvoet (gemiddelde loonkosten per manjaar) toeneemt $\left(\alpha_{2}<0\right)$.

Indien de loonvoet toeneemt, zal ten eerste dit veroorzaakt worden door een hogere kwaliteit van arbeid en ten tweede zal de eigenaar/bedrijfsleider zijn beschikbare arbeid beter plannen. Beide invloeden wijzen in de richting van een verlaging van de arbeidsintensiteit.

Stelling 6: schaalgecorrigeerde vloerintensiteit neemt af naarmate de huurwaarde per $\mathrm{m}^{2}$ bedrijfsoppervlakte toeneemt $\left(\beta_{2}<0\right)$.

Indien de huurwaarde per $\mathrm{m}^{2}$ toeneemt, zal ten eerste dit veroorzaakt worden door een hogere kwaliteit van het vestigingspunt en ten tweede zal de eigenaar/bedrijfsleider zijn beschikbare ruimte beter plannen. Beide invloeden wijzen in de richting van een verlaging van de vloerintensiteit. 
Stelling 7: schaalgecorrigeerde arbeidsintensiteit neemt af naarmate voor een winkeltype minder ambacht voorkomt en meer zelfbediening $\left(\alpha_{3}<0\right)$. De gedachte hierachter is dat ambacht en bediening arbeidsintensief zijn. We introduceren de variabele 'procentuele verkoopvloeroppervlakte' (verkoopvloeropppervlakte gedeeld door totale bedrijfsoppervlakte). Indien de mate van zelfbediening toeneemt, zal de procentuele verkoopvloeroppervlakte toenemen. Als de mate van ambacht toeneemt, zal de procentuele verkoopvloeroppervlakte afnemen, indien de desbetreffende vorm van ambacht niet op de verkoopvloeroppervlakte wordt uitgeoefend. Kapperszaken worden niet in de analyse betrokken, aangezien hier het ambacht in de 'publiekruimte' wordt uitgeoefend. Stelling 7 zal dus in de volgende vorm getoetst worden: schaalgecorrigeerde arbeidsintensiteit neemt af naarmate voor een winkeltype de procentuele verkoopvloeroppervlakte toeneemt.

Stelling 8: schaalgecorrigeerde vloerintensiteit neemt toe naarmate voor een winkeltype minder ambacht voorkomt en meer zelfbediening $\left(\beta_{3}>0\right)$.

De gedachte hierachter is dat ambacht en bediening weinig vloerintensitief zijn. Ook hier wordt de variabele 'procentuele verkoopvloeroppervlakte' gebruikt. Stelling 8 zal dus in de volgende vorm getoetst worden: schaalgecorrigeerde vloerintensiteit neemt toe naarmate voor een winkeltype de procentuele verkoopvloeroppervlakte toeneemt.

Stelling 9: schaalgecorrigeerde arbeidsintensiteit neemt af naarmate voor een winkeltype het percentage ondernemersarbeid (inclusief familiearbeid) toeneemt $\left(\alpha_{4}<0\right)$.

De grotere betrokkenheid van de ondernemer en medewerkende gezinsleden zal leiden tot een hogere arbeidsproduktiviteit dan die van werknemers. Voorts zullen gezinsleden alleen meewerken als het echt nodig is en dan dus een hoge arbeidsproduktiviteit opleveren.

Stelling 10: schaalgecorrigeerde arbeidsintensiteit hangt af van het feit of een winkeltype voedings- en genotmiddelen verkoopt of duurzame en overige goederen $\left(\alpha_{5}\right.$ ?).

Over het 'teken' van deze afhankelijkheid willen we geen a priori uitspraak doen.

Stelling 11: schaalgecorrigeerde vloerintensiteit hangt af van het feit of een winkeltype voedings- en genotmiddelen verkoopt of duurzame en overige goederen $\left(\beta_{5}\right.$ ?).

Ook over het 'teken' van deze afhankelijkheid willen we geen a priori uitspraak doen. Echter een lagere vloerintensiteit voor winkeltypen, die voedings- en genotmiddelen verkopen, zou ons niet verbazen in verband met een hogere omzetsnelheid.

\section{Conclusies}

In deze studie worden gegeneraliseerde kostenrelaties bestudeerd voor de detailhandel. Deze beschrijven de relatie tussen enerzijds gemiddelde arbeid of gemiddelde bedrijfsvloeroppervlakte en anderzijds gemiddelde waarde van de jaarlijkse omzet per vestiging voor vele verschillende winkeltypen in de detailhandel. 
Uit de schattingen met behulp van de exploitatiegegevens 1981 van de E.I.M.-Bedrijfssignalering blijkt dat:

I de gevonden waarden van de drempelcoëfficiënten in overeenstemming zijn met de theoretische a priori waarden (stelling 1 en 3). De drempelcoëfficiënten spelen een belangrijke rol in de afleiding van de gegeneraliseerde kostenrelaties uit de kostenrelaties per winkeltype. De drempelcoëfficiënten geven de hoeveelheid arbeid, respectievelijk oppervlakte weer die in een detailhandelsvestiging aanwezig moet zijn, onafhankelijk van hun benutting. Voorts zijn we in staat gebleken aan te tonen dat grotere winkeltypen een grotere drempelvloeroppervlakte nodig hebben dan kleinere (stelling 4);

II verschillen in arbeids- en vloerintensiteit tussen winkeltypen, die natuurlijk in ruime mate aanwezig zijn, op bevredigende wijze verklaard kunnen worden met behulp van een gering aantal factoren. Voor de gegeneraliseerde arbeidskostenrelatie zijn deze factoren: gemiddelde jaarlijkse waarde van de omzet per vestiging, gemiddelde loonkosten per arbeidsjaar, gemiddelde procentuele verkoopvloeroppervlakte, gemiddelde procentuele ondernemersarbeid en de aanduiding of een winkeltype voedings- en genotmiddelen verkoopt of duurzame en overige goederen. Voor de gegeneraliseerde vloeroppervlaktekostenrelatie zijn dezelfde factoren gebruikt, met uitzondering van gemiddelde procentuele ondernemersarbeid. Stellingen 5 tot en met 9 worden zonder meer door onze empirische exercities ondersteund. Winkeltypen die voedings- en genotmiddelen verkopen, hebben een lagere arbeids- en vloerintensiteit dan typen die duurzame en overige goederen verkopen (stelling 10 en 11). De variabele 'procentuele verkoopvloeroppervlakte' (verkoopvloeroppervlakte gedeeld door totale bedrijfsoppervlakte) lijkt een interessante variabele te zijn om op geaggregeerd niveau winkeltypen te duiden. Dit percentage zal toenemen indien de mate van zelfbediening toeneemt of de mate van ambacht afneemt (indien deze laatste niet op de verkoopvloeroppervlakte wordt uitgeoefend);

III de verklaring van de gebruikte relaties zeer hoog is en de geschatte coëfficiënten systematisch zeer kleine standaardfouten hebben;

IV de schattingsresultaten wat betreft de arbeidskostenrelatie vergelijkbaar zijn met die voor 39 Franse winkeltypen uit 1978, waarbij ongeveer 400.000 vestigingen betrokken zijn ${ }^{6}$.

Met uitzondering van stelling 2 worden alle 11 stellingen door onze empirische schattingen ondersteund.

Zie Appendix B voor de precieze schattingsresultaten.

Voorts is er reden tot tevredenheid, omdat deze exercities zijn uitgevoerd met het door het E.I.M. ontwikkelde bedrijfssignaleringssysteem dat periodiek (maand, kwartaal, jaar) een meting doet bij enige duizenden detailhandelsbedrijven. Het gebruik van dit systeem belooft enige interessante toepassingen. Deze worden in de volgende paragraaf beschreven. 


\section{Toepassingen}

Voor toepassingen van gegeneraliseerde kostenrelaties denken we aan de volgende onderzoekterreinen:

I omgevings- of regionale analyse. De invloed van vestigingsplaats of regionale kenmerken op de coëfficiënten van de kostenrelaties kunnen onderzocht worden door het basisbestand van individuele vestigingen (ondernemingen) te splitsen in verschillende klassen. Klasse-indelingen zijn bijvoorbeeld: vestigingen in grote of kleine steden; vestigingen in grote of kleine winkelcentra, vestigingen in de randstad of daarbuiten etc. Per klasse-indeling wordt er een schatting gemaakt en de respectievelijke geschatte coëfficiënten worden vergeleken. Vooral verschillen in de geschatte coëfficiënten van de voor schaal en overige winkeltypeeigenschappen (loonvoet, procentuele verkoopvloeroppervlakte, procentuele ondernemersarbeid en produktgroep) gecorrigeerde arbeidsintensiteit en van de voor schaal en overige winkeltype-eigenschappen (huurwaarde, procentuele verkoopvloeroppervlakte en produktgroep) gecorrigeerde vloerintensiteit komen in aanmerking voor interpretatie. Wanneer we buiten het bedrijfssignaleringssysteem treden, zou ook een internationale vergelijking interessant zijn;

II ontwikkeling in de tijd. De schattingen die in deze studie zijn beschreven, hebben betrekking op 1981. Wanneer identieke schattingen voor oudere of, liever nog, recentere jaren kunnen worden gemaakt, ontstaat de mogelijkheid een vergelijking in de tijd te maken. Bijvoorbeeld in het geval van de arbeidskostenrelatie kan de ontwikkeling bestudeerd worden van:

- de intensiteit van de invloed van specifieke winkeltype-eigenschappen (loonvoet, procentuele verkoopvloeroppervlakte, procentuele ondernemersarbeid en produktgroep) op de voor schaalgecorrigeerde arbeidsintensiteit;

- de arbeidsintensiteit van het midden- en kleinbedrijf in de detailhandel in het algemeen. Hiertoe worden de voor schaal en overige winkeltype-eigenschappen gecorrigeerde arbeidsintensiteiten vergeleken;

- de relatieve 'performance' van een bepaald winkeltype. Hiertoe wordt de ontwikkeling van het verschil beschouwd dat ontstaat wanneer het echte gemiddelde arbeidsvolume per vestiging en het met de arbeidskostenrelatie geschatte wordt vergeleken voor een bepaald winkeltype;

III analyse van organisatievormen. De schattingen die in deze studie zijn opgeschreven, hebben betrekking op vestigingen behorende tot ondernemingen met één vestiging, alsmede op vestigingen behorende tot ondernemingen met meer vestigingen. Het basisbestand kan gesplitst worden volgens deze klasse-indeling en de respectievelijke schattingen van de kostenrelaties kunnen weer vergeleken worden. Evenzo kan de invloed van coöperatieve samenwerkingsverbanden worden bestudeerd;

IV verdieping van onderzoekspecificatie. Het is interessant de specificatie van de arbeidskostenrelatie uit te breiden met bijvoorbeeld de variabele 'percentage part-time arbeid'. 
Uitgebreide analyses op het gebied van individuele vestigingen per winkeltype ${ }^{\bar{\gamma}}$ hebben de invloed van deze variabele nooit onomstotelijk kunnen aantonen. Er zijn theoretische overwegingen om aan te nemen dat haar invloed van belang is;

$\mathrm{V}$ verklaring van het complete gemiddelde exploitatiebeeld per winkeltype. In het kostenbeeld ontbreekt nog de verklaring van de gemiddelde overige exploitatiekosten per winkeltype en in het complete gemiddelde exploitatiebeeld de verklaring van de gemiddelde winstmarge. De eerste studie is reeds voltooid ${ }^{8}$, terwijl de tweede in uitvoering is. Bij de verklaring van de winstmarge gaan we uit van de reeds eerder ontwikkelde relatie van de verklaring van de gemiddelde procentuele brutomarge;

VI macrorelaties. De analyses, waarvan in deze studie verslag is gedaan, zijn wellicht een stap in de richting van een arbeidskostenrelatie op hoog aggregatieniveau (hele sector detailhandel). Een nadeel van het bedrijfssignaleringssysteem is dat uitsluitend vestigingen van kleine ondernemingen zijn opgenomen.

* Auteurs zijn hoofd, respectievelijk wetenschappelijk assistent op de afdeling Onderbouwend Onderzoek van het Economisch Instituut voor het Midden- en Kleinbedrijf (E.I.M.)

Noten

1 De theoretische onderbouwing is gegeven door Nooteboom [1982].

2 Zie Nooteboom [1980] en Ingene [1983] voor literatuurreferenties.

3 Zie Nooteboom [1980], Thurik en Van der Wijst [1982] en Thurik [1984a].

4 Zie Nooteboom [1983].

5 Zie Thurik en Koerts [1984a] en [1984b].

6 Zie Thurik en Vollebregt [1984].

7 Zie Thurik en Van der Wijst [1982]. Zie Nooteboom [1983] en Thurik en Vollebregt [1984] voor resultaten op winkeltypeniveau.

8 Zie Thurik [1984b].

9 Zie Nooteboom [1980].

\section{Literatuur}

Bedrijfssignalering: Bedrijfsresultaten 1981, 1983, E.I.M.

Ingene, Ch. A., 1983, Are there scale economies in American retailing?, paper for presentation at the 1983 Macromarketing Conference.

Marquardt, D. W., 1963, An algorithm for least squares estimation of nonlinear parameters, Journal of the society for industrial and applied mathematics, 11, 431-441.

Nooteboom, B., 1980, Retailing: applied analysis in the theory of the firm (J. C. Gieben, Uithoorn).

Nooteboom, B., 1982, A new theory of retailing costs, European economic review, 17, 163-186.

Nooteboom, B., 1983, Productivity growth in the grocery trade, Applied economics, 15, 649664.

Thurik, A. R., 1984a, Labour productivity and opening time in large retail establishments, Service industries journal, Vol. 4, No. 1.

Thurik, A. R., 1984b, Overige exploitatiekosten in de detailhandel, Kuantitatieve methoden, $13,108-119$.

Thurik, A. R. en J. Koerts, 1984a, On the use of supermarket floorspace and its efficiency, in.: The economics of distribution (Franco Angeli Editore, Milano), 387-445.

Thurik, A. R. en J. Koerts, 1984b, Analysis of the use of retail floorspace, International small business journal, Vol. 4, No. 1, 35-47.

Thurik, A. R. en J. A. C. Vollebregt, 1984, A generalized labour cost relation for French retailing, Les annales de l'INSEE, 53, 93-106.

Thurik, A. R. en D. van der Wijst, 1982, Part-time labour and labour productivity in retailing, Report 8244/S, Erasmus Universiteit Rotterdam. 


\section{Appendix A: gebruikte data}

De gebruikte data zijn afkomstig uit het boekje Bedrijfssignalering: Bedrijfsresultaten '81 [1983] dat een overzicht geeft van de gemiddelde exploitatieoverzichten over 1981 van 49 branches/bedrijfstypen in het midden- en kleinbedrijf. Deze data zijn aangevuld met gemiddeld aantal werkzame personen, gemiddelde bedrijfsvloeroppervlakte en gemiddelde verkoopvloeroppervlakte per bedrijfstype. De kappersbedrijven zijn uit de analyse weggelaten, omdat hier eigenlijk geen sprake meer is van detailhandel maar van ambacht. Als eenheden van onderzoek zijn de gemiddelde waarden van de omzetklassen per bedrijfstype genomen. Voor sommige bedrijfstypen zijn er drie omzetklassen, voor sommige slechts één. Het totaal aantal waarnemingen is dan 85 . Gegevens van 1.783 detailhandelsvestigingen, behorende tot 1.538 ondernemingen zijn gebruikt om deze gemiddelden te berekenen. De grootste omzetklasse van de levensmiddelensupermarkten is weggelaten, omdat de gemiddelde omzet $\pm 50 \%$ groter is dan die van enige andere omzetklasse. De gebruikte data zijn in tabel A1 opgeschreven. In deze tabel zijn de volgende afkortingen gebruikt:

$\mathrm{Q}$ : waarde van de jaarlijkse omzet in $10^{5}$ guldens;

$\mathrm{L} \quad$ : aantal werkzame personen in full-time equivalenten;

BV : bedrijfsvloeroppervlakte in $\mathrm{m}^{2}$;

PVO: procentuele verkoopvloeroppervlakte (percentage van BV);

HW : huurwaarde per $\mathrm{m}^{2}$ in guldens;

$\mathrm{LV}$ : loonvoet per full-time equivalent in $10^{3}$ guldens;

POA: procentuele ondernemersarbeid (percentage van totale arbeid).

\begin{tabular}{|c|c|c|c|c|c|c|c|}
\hline $\begin{array}{l}\text { Tahel } A 1 \text { gebruikte data } \\
\text { rekengroep }\end{array}$ & $Q$ & $L$ & $B V$ & $P V O$ & $H W$ & $L V$ & $P O A$ \\
\hline \multirow[t]{2}{*}{1010 sup met amb slagerij } & 19.05 & 7.53 & 430.41 & 66 & 168.19 & 34.66 & 36 \\
\hline & 27.66 & 10.68 & 551.06 & 70 & 165.63 & 32.63 & 29 \\
\hline \multirow[t]{3}{*}{1030 zelfbedieningszaken (ALH) } & 4.37 & 2.34 & 142.11 & 57 & 67.65 & 36.46 & 86 \\
\hline & 8.49 & 3.81 & 193.04 & 66 & 79.16 & 33.67 & 67 \\
\hline & 12.96 & 4.85 & 272.78 & 65 & 142.53 & 33.11 & 58 \\
\hline \multirow[t]{3}{*}{1110 slagers } & 3.77 & 2.65 & 80.03 & 49 & 179.02 & 38.34 & 76 \\
\hline & 5.74 & 3.38 & 92.93 & 46 & 290.32 & 29.24 & 54 \\
\hline & 9.54 & 4.95 & 121.16 & 42 & 393.9 & 40.14 & 42 \\
\hline \multirow[t]{3}{*}{$1210 \mathrm{AGF}$} & 2.74 & 1.86 & 67.89 & 55 & 137.22 & 37.34 & 84 \\
\hline & 5.2 & 3.33 & 112.65 & 48 & 156.94 & 37.44 & 70 \\
\hline & 7.47 & 3.62 & 122.52 & 43 & 195.01 & 37.08 & 59 \\
\hline \multirow[t]{2}{*}{1320 Zuivel + ambulante handel } & 2.97 & 1.94 & 56.92 & 39 & 62.62 & 39.17 & 100 \\
\hline & 5.6 & 2.21 & 64.02 & 53 & 148.7 & 42.25 & 95 \\
\hline \multirow[t]{2}{*}{1330 Zuivel + rijdende winkel } & 4.58 & 2.18 & 62.46 & 46 & 197.99 & 39.27 & 96 \\
\hline & 7.09 & 2.52 & 87.11 & 48 & 154.56 & 38.78 & 88 \\
\hline \multirow[t]{2}{*}{1370 kaaswinkels } & 3.31 & 1.69 & 77.96 & 60 & 297.22 & 35.48 & 84 \\
\hline & 5.6 & 2.28 & 99.93 & 62 & 285.8 & 36.41 & 77 \\
\hline \multirow[t]{2}{*}{1410 viszaken } & 2.19 & 1.52 & 34.38 & 66 & 337.88 & 39.74 & 95 \\
\hline & 6.77 & 3.96 & 107.99 & 49 & 300.91 & 36.25 & 57 \\
\hline \multirow[t]{2}{*}{1560 brood banket } & 3.23 & 3.71 & 121.21 & 26 & 237.27 & 38.45 & 56 \\
\hline & 5.08 & 4.84 & 142.79 & 27 & 313.1 & 40 & 35 \\
\hline \multirow[t]{2}{*}{1910 sup zonder amb slagerij } & 12.78 & 5.61 & 289.01 & 72 & 110.55 & 31.46 & 54 \\
\hline & 30.1 & 9.53 & 485.01 & 75 & 248.24 & 32.23 & 31 \\
\hline \multirow[t]{2}{*}{2010 banketwinkels } & 2.97 & 3.54 & 117.09 & 37 & 230.87 & 36.71 & 55 \\
\hline & 6.36 & 7.48 & 213.34 & 24 & 235.5 & 38.93 & 31 \\
\hline
\end{tabular}




\begin{tabular}{|c|c|c|c|c|c|c|c|}
\hline $\begin{array}{l}\text { Tabel A1 gebruikte data } \\
\text { rekengroep }\end{array}$ & $Q$ & $L$ & $B V$ & $P V O$ & $H W$ & $L V$ & $P O A$ \\
\hline \multirow[t]{2}{*}{2110 tabakzaken } & 3.85 & 1.44 & 61.95 & 77 & 136.73 & 37.79 & 91 \\
\hline & 8.68 & 2.3 & 53.98 & 69 & 321.6 & 38.83 & 77 \\
\hline \multirow{2}{*}{2210 slijters $>60 \%$ gedist. } & 4.05 & 1.55 & 88.76 & 71 & 109.51 & 38.25 & 98 \\
\hline & 7.07 & 2.18 & 119.27 & 59 & 142.32 & 38.67 & 72 \\
\hline 2220 slijters $\leqslant 60 \%$ gedist. & 6.2 & 1.68 & 184.23 & 47 & 107.68 & 42.55 & 68 \\
\hline \multirow[t]{3}{*}{3010 herenkleding } & 3.45 & 1.87 & 139.11 & 70 & 180.97 & 39.01 & 90 \\
\hline & 5.54 & 2.56 & 181.24 & 71 & 207.67 & 40.39 & 61 \\
\hline & 10.6 & 4.82 & 353.81 & 79 & 185.81 & 43.34 & 32 \\
\hline \multirow[t]{3}{*}{3020 dameskleding } & 3.37 & 2.48 & 120.78 & 76 & 164.61 & 36.18 & 62 \\
\hline & 5.74 & 3.48 & 200.3 & 79 & 183.3 & 37.62 & 49 \\
\hline & 9.62 & 5.06 & 272.73 & 73 & 208.15 & 36.40 & 34 \\
\hline \multirow[t]{2}{*}{3030 dames-en herenkleding } & 4.07 & 3.11 & 243.36 & 84 & 110.42 & 35.63 & 63 \\
\hline & 8.28 & 4.76 & 404.41 & 83 & 110.54 & 36.54 & 44 \\
\hline 3040 VT-kleding & 4.62 & 2.02 & 126.83 & 77 & 189.54 & 39.16 & 56 \\
\hline \multirow[t]{2}{*}{3060 foundations } & 3.43 & 2.93 & 91.1 & 81 & 248.49 & 35.33 & 60 \\
\hline & 5.78 & 3.96 & 144.38 & 83 & 332.41 & 35.04 & 53 \\
\hline 3070 wol-handwerk & 3.46 & 2.65 & 139.21 & 72 & 156.81 & 35.89 & 55 \\
\hline \multirow[t]{2}{*}{3100 niet gesp. textiel } & 1.86 & 1.69 & 105.11 & 73 & 79.56 & 36.19 & 81 \\
\hline & 4.22 & 2.69 & 272.16 & 79 & 102.43 & 39.09 & 68 \\
\hline \multirow[t]{3}{*}{3210 schoenen } & 2.76 & 2.28 & 114.52 & 56 & 115.68 & 35.94 & 79 \\
\hline & 5.40 & 3.17 & 172.41 & 59 & 143.05 & 38.92 & 64 \\
\hline & 7.45 & 4.36 & 175.22 & 60 & 233.91 & 35.23 & 41 \\
\hline \multirow[t]{2}{*}{3310 sportartikelen } & 3.65 & 2.16 & 156.99 & 64 & 102.3 & 40.56 & 84 \\
\hline & 8.62 & 4.25 & 387.94 & 66 & 95.59 & 36.74 & 45 \\
\hline \multirow[t]{2}{*}{3510 huish art } & 3.95 & 2.64 & 231.57 & 68 & 69.99 & 37.5 & 75 \\
\hline & 9.62 & 5.56 & 626.63 & 57 & 66 & 33.56 & 46 \\
\hline 3520 speelgoed & 5.74 & 3.56 & 389.6 & 73 & 101.64 & 33.97 & 41 \\
\hline 3670 electr. art & 8.21 & 4.21 & 183.1 & 63 & 134.52 & 40.36 & 45 \\
\hline \multirow[t]{3}{*}{3710 woninginr. vn meubels } & 6.6 & 2.95 & 854.92 & 80 & 46.32 & 42.56 & 53 \\
\hline & 14 & 5.41 & 1466.3 & 80 & 61.12 & 44.55 & 34 \\
\hline & 18.88 & 8.03 & 1781 & 78 & 54.06 & 40.89 & 22 \\
\hline \multirow[t]{2}{*}{3720 woninginr. vn textiel } & 4.2 & 2.75 & 236.09 & 71 & 78.28 & 41 & 63 \\
\hline & 8.76 & 4.52 & 418.43 & 74 & 117.26 & 43.07 & 49 \\
\hline \multirow[t]{3}{*}{3740 woninginr. gemengd } & 5.09 & 2.78 & 436.99 & 70 & 48.93 & 41.36 & 59 \\
\hline & 9.32 & 4.7 & 1027.03 & 79 & 48.98 & 42.17 & 39 \\
\hline & 17.62 & 8.77 & 2023.51 & 73 & 43.55 & 40.6 & 26 \\
\hline 3820 verf, glas en behang & 3.96 & 3.19 & 145.86 & 66 & 124.89 & 40.05 & 47 \\
\hline \multirow[t]{2}{*}{3840 ijzerwaren } & 3.28 & 2.12 & 259.08 & 69 & 86.09 & 39.83 & 91 \\
\hline & 7.61 & 3.73 & 397.81 & 73 & 97.51 & 41.62 & 48 \\
\hline \multirow[t]{3}{*}{3910 fietsen $>25 \%$ rep. } & 2.04 & 1.52 & 114.29 & 53 & 58.9 & 38.19 & 92 \\
\hline & 4.21 & 2.3 & 266.44 & 58 & 48.65 & 41.54 & 74 \\
\hline & 7.93 & 3.78 & 308.68 & 53 & 92.48 & 41.37 & 60 \\
\hline 3920 fietsen $\leqslant 25 \%$ rep. & 3.37 & 2.04 & 192.02 & 48 & 73.71 & 39.76 & 80 \\
\hline & 7.43 & 3.46 & 410.04 & 49 & 54.36 & 41.71 & 55 \\
\hline 4010 fotozaken & 3.14 & 2.36 & 78.72 & 62 & 251.24 & 38.17 & 61 \\
\hline & 7.27 & 3.46 & 159.16 & 64 & $228 / 35$ & 44.94 & 36 \\
\hline 4110 opticiens & 2.03 & 1.64 & 93.85 & 59 & 231.44 & 38.13 & 89 \\
\hline & 5.36 & 3.33 & 108.94 & 66 & 403.44 & 47.49 & 39 \\
\hline 4120 goud, zilver en uurwerken & 3.49 & 2.46 & 81.92 & 63 & 234.3 & 41.04 & 67 \\
\hline & 6.38 & 4.31 & 122.7 & 56 & 301.66 & 39.22 & 43 \\
\hline 5130 boek- en kantoorboekh. & 5.4 & 3.27 & 183.11 & 75 & 147.45 & 36.3 & 69 \\
\hline & 14.54 & 7.2 & 363.74 & 57 & 179.91 & 38.99 & 27 \\
\hline 5210 drogisterijen & 2.83 & 2.05 & 105.61 & 63 & 131.17 & 36.29 & 81 \\
\hline & 5.11 & 3.45 & 170.26 & 67 & 138.09 & 36.85 & 57 \\
\hline & 8.19 & 5.08 & 197.65 & 71 & 252.66 & 33.81 & 37 \\
\hline 5410 bloemen en planten & 1.85 & 2.15 & 101.09 & 67 & 11.63 & 37.07 & 85 \\
\hline & 3.33 & 2.92 & 144.3 & 74 & 152.39 & 36.94 & 69 \\
\hline & 5.45 & 3.86 & 253.51 & 62 & 88.11 & 39.62 & 50 \\
\hline 5510 dieren hengelsport & 2.26 & 1.86 & 120.66 & 64 & 121.55 & 37.15 & 82 \\
\hline & 4.81 & 2.47 & 161.61 & 73 & 181.47 & 36.27 & 62 \\
\hline
\end{tabular}




\section{Appendix B: schattingsvergelijkingen en -resultaten}

We gaan uit van een lineaire niet-homogene relatie tussen arbeid en omzet voor vestigingen van een bepaald winkeltype:

$$
\mathrm{L}_{\mathrm{ij}}=x_{\mathrm{oj}}+x_{1 \mathrm{j}} \mathrm{Q}_{\mathrm{ij}} \text { met } x_{0 \mathrm{j}}>0 \text { en } x_{1 \mathrm{j}}>0 \text {, }
$$

waarbij: $\mathrm{L}_{\mathrm{ij}}$ : arbeidsvolume in vestiging $\mathrm{i}$ van winkeltype $\mathrm{j}$;

$Q_{i j}$ : jaarlijkse omzet in vestiging i van winkeltype $j$;

$\alpha_{\mathrm{oj}}$ : drempelcoëfficiënt;

$\alpha_{1 j}$ : hoekcoëfficiënt (de voor schaal gecorrigeerde arbeidsintensiteit).

We veronderstellen (volgens stelling 2):

$$
\begin{aligned}
& x_{0 j}=\alpha_{0}+\alpha_{o 1} D_{j} \text { met } x_{o}>0 \text { en } x_{o 1}>0, \\
& \text { waarbij: } \mathrm{DD}_{\mathrm{j}}=1 \text { voor winkeltypen die meer dan één onafkan- } \\
& \text { kelijk bemande afdeling hebben en } \\
& \mathrm{DD}_{\mathrm{j}}=0 \quad \text { voor de overige winkeltypen; } \\
& \alpha_{0} \text { : drempelarbeid voor winkeltypen met één onaf- } \\
& \text { hankelijk bemande afdeling; } \\
& x_{01} \quad \text { : additionele drempelarbeid voor winkeltypen } \\
& \text { met meer dan één onafhankelijk bemande af- } \\
& \text { deling. }
\end{aligned}
$$

Simpele aggregatie geeft nu:

$$
\mathrm{L}_{\mathrm{j}}=\alpha_{0}+\alpha_{01} \mathrm{DD}_{\mathrm{j}}+\alpha_{1 \mathrm{j}} \mathrm{Q}_{\mathrm{j}}
$$

waarbij: $\mathrm{L}_{\mathrm{j}}$ : gemiddelde arbeidsvolume per vestiging in winkeltype $\mathrm{j}$;

$Q_{j} \quad$ : gemiddelde jaarlijkse omzet per vestiging in winkeltype j.

Op dezelfde wijze verkrijgen we:

$$
\begin{aligned}
& \mathrm{BV}_{\mathrm{j}}=\beta_{\mathrm{o}}+\beta_{\mathrm{o} 1} \mathrm{DD}_{\mathrm{j}}+\beta_{\mathrm{lj}} \mathrm{Q}_{\mathrm{j}}, \\
& \begin{aligned}
& \text { waarbij: } \mathrm{BV}, \quad \text { gemiddelde bedrijfsoppervlakte per vestiging } \\
& \text { in winkeltype } \mathrm{j} ; \\
& \beta_{\mathrm{o}}, \beta_{\mathrm{o} 1}: \text { drempeloppervlakten; } \\
& \beta_{1 \mathrm{j}}: \text { hoekcoëfficiënt (de voor schaal gecorrigeerde } \\
&
\end{aligned}
\end{aligned}
$$

Op grond van de in paragraaf 3 genoemde stellingen $5,7,9$ en 10 stellen we de volgende specificatie van $\alpha_{1 j}$, de (voor schaal gecorrigeerde) arbeidsintensiteit, voor: 


$$
\alpha_{\mathrm{tj}}=\alpha_{1}\left(\frac{\mathrm{LV}_{\mathrm{i}}}{\mathrm{L} \overline{\mathrm{V}}}\right)^{\alpha_{2}}\left(\frac{\mathrm{PVO}_{\mathrm{j}}}{\mathrm{PVO}}\right)^{\alpha_{3}}\left(\frac{\mathrm{POA}_{\mathrm{j}}}{\mathrm{P} \overline{\mathrm{OA}}}\right)^{\alpha_{4}} \exp \left(\alpha_{5} \mathrm{DFO}_{\mathrm{J}}\right)
$$

waarbij: $\mathrm{LV}_{\mathrm{j}}$ : gemiddelde loonvoet (inclusief gewaardeerd loon) per manjaar in winkeltype $\mathrm{j}$;

$\mathrm{PVO}_{\mathrm{j}}$ : gemiddelde procentuele verkoopvloeroppervlakte in winkeltype $\mathrm{j}$;

$\mathrm{POA}_{\mathrm{j}}$ : gemiddelde procentuele ondernemersarbeid (inclusief familie-arbeid)in winkeltype j. Deze variabele is geconstrueerd door de gewaardeerde lonen te delen door de som van de gewaardeerde lonen en uitbetaalde lonen;

$\mathrm{DFO}_{\mathrm{j}}$ : dummyvariabele die de waarde 1 aanneemt als winkeltype $\mathrm{j}$ voedings- en genotmiddelen verkoopt en de waarde 0 als het winkeltype duurzame en overige goederen verkoopt;

$\mathrm{LV}$ : gemiddelde loonvoet over alle winkeltypen;

$\mathrm{PVO}$ : gemiddelde procentuele verkoopvloeroppervlakte over alle winkeltypen;

$\mathrm{POA}$ : gemiddelde procentuele ondernemersarbeid over alle winkeltypen.

De coëfficiënten hebben nu de volgende interpretatie:

$x_{1}$ : arbeidsintensiteit gecorrigeerd voor schaal, verschillen in gemiddelde looonvoet, gemiddelde procentuele verkoopvloeroppervlakte, gemiddelde procentuele ondernemersarbeid en voor winkeltypen met duurzame en overige goederen;

$\alpha_{2}$ : invloed van de gemiddelde loonvoet op deze arbeidsintensiteit (stelling 5 veronderstelt dat $\alpha_{2}<0$ );

$\alpha_{3}$ : invloed van de gemiddelde procentuele verkoopvloeroppervlakte op deze arbeidsintensiteit (stelling 7 veronderstelt dat $\alpha_{3}<0$ );

$\alpha_{4}$ : invloed van de gemiddelde procentuele ondernemersarbeid op deze arbeidsintensiteit (stelling 9 veronderstelt dat $\alpha_{4}<0$ );

$\alpha_{5}$ : correctie op deze arbeidsintensiteit voor winkeltypen die voedings- en genotmiddelen verkopen.

Op grond van de in paragraaf 3 genoemde stellingen 6,8 en 11 stellen we de volgende specificatie van $\beta_{1 \mathrm{j}}$, de (voor schaal gecorrigeerde) vloerintensiteit, voor:

$$
\beta_{1 j}=\beta_{1}\left(\frac{H W_{j}}{H \bar{W}}\right) \beta_{2} \underset{\left(\frac{P V O}{P V O}\right)}{\beta_{3}} \exp \left(\beta_{5} D_{F} O_{j}\right),
$$

waarbij: $\mathrm{HW}_{\mathrm{j}}$ : gemiddelde huurwaarde per $\mathrm{m}^{2}$ bedrijfsvloeroppervlakte in winkeltype $\mathrm{j}$;

$H \bar{W}$ : gemiddelde huurwaarde over alle winkeltypen. 
De coëfficiënten hebben nu de volgende interpretatie:

$\beta_{1}$ : vloerintensiteit gecorrigeerd voor schaal, verschillen in gemiddelde huurwaarde, gemiddelde procentuele verkoopvloeroppervlakte en voor winkeltypen met duurzame en overige goederen;

$\alpha_{2}$ : invloed van de gemiddelde huurwaarde op deze vloerintensiteit (stelling 6 veronderstelt dat $\beta_{2}<0$ );

$\beta_{3}$ : invloed van de gemiddelde procentuele verkoopvloeroppervlakte op deze vloerintensiteit (stelling 8 veronderstelt dat $\beta_{3}>0$ );

$\beta_{5}$ : correctie op deze vloerintensiteit voor winkeltypen die voedings- en genotmiddelen verkopen.

Wanneer vergelijking (B5) in (B3) en vergelijking (B6) in (B4) wordt gesubstitueerd, dan ontstaan:

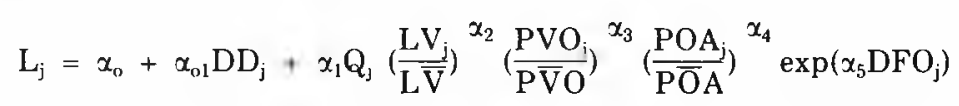

en

$$
\begin{array}{ll}
\mathrm{BV}_{\mathrm{j}}=\beta_{\mathrm{o}}+\beta_{01} \mathrm{DD}_{\mathrm{j}}+\beta_{1} \mathrm{Q}_{\mathrm{j}}\left(\frac{\mathrm{HW}}{\mathrm{HW}}\right)^{\beta_{2}}\left(\frac{\mathrm{PVO}_{\mathrm{W}}}{\mathrm{P} \overline{\mathrm{V}}}\right)^{\beta_{3}} \exp \left(\beta_{5} \mathrm{DFO}_{\mathrm{j}}\right), \\
\text { waarbij: } \begin{array}{ll}
\mathrm{L}_{\mathrm{j}} & \text { wordt uitgedrukt in manjaren, } \\
& \mathrm{BV}_{\mathrm{j}} \quad \text { in } \mathrm{m}^{2} \text { en } \\
\mathrm{Q}_{\mathrm{j}} & \text { in honderdduizenden guldens exclusief B.T.W. }
\end{array}
\end{array}
$$

Vergelijkingen (B7) en (B8) zijn niet-lineair. Een niet-lineaire schattingsprocedure zal dan ook gebruikt worden om de geschatte waarde van de coëfficiënten vast te stellen. De kwadratensom van de storingstermen wordt numeriek geminimeerd nadat deze termen additief zijn toegevoegd. De door ons gebruikte minimaliseringsmethode is die van Marquardt [1963].

tabel B1 schattingen van coëfficiënten van de arbeidsvergelijking (B7) met b.s.s.jaarcijfers in 1981

\begin{tabular}{lccccccccc}
\hline & $x_{0}$ & $\alpha_{01}$ & $\alpha_{4}$ & $\alpha_{2}$ & $\alpha_{3}$ & $\alpha_{4}$ & $\alpha_{5}$ & $J$ & $\rho^{2}$ \\
\hline schatting & 1.49 & -.20 & .30 & -1.22 & -1.13 & -.57 & -.40 & 85 & .94 \\
& $(.16)$ & $(.49)$ & $(.03)$ & $(.29)$ & $(.09)$ & $(.13)$ & $(.07)$ & & \\
stelling & 1.25 & $>0$ & $>0$ & $<0$ & $<0$ & $<0$ & $?$ & & \\
\hline
\end{tabular}

tabel B2 schattingen van coëfficiënten van de oppervlaktevergelijking (B8) met b.s.s.-jaarcijfers 1981

\begin{tabular}{lcccccccc}
\hline & $\beta_{0}$ & $\beta_{01}$ & $\beta_{1}$ & $\beta_{2}$ & $\beta_{3}$ & $\beta_{5}$ & $\mathrm{~J}$ & $\rho^{2}$ \\
\hline schatting & 42.9 & 79.8 & 24.0 & -.99 & 1.40 & -.61 & 85 & .98 \\
& $(10.8)$ & $(37.8)$ & $(1.9)$ & $(.05)$ & $(.18)$ & $(.10$ & & \\
stelling & 40. & $>0$ & $>0$ & $<0$ & $>0$ & $?$ & & \\
\hline
\end{tabular}


De tussen haakjes geplaatste getallen geven de geschatte standaardfouten weer van de geschatte coëfficiënten. Deze fout is een indicatie van de mate van betrouwbaarheid van de geschatte coëfficiënt. Naarmate de fout kleiner is ten opzichte van de waarde van de coëfficiënt, is deze laatste waarde betrouwbaarder. Vaak zijn we tevreden wanneer de fout de helft is van de waarde van de coëfficiënt.

In ons geval zien we dat in de tabellen B1 en B2 de fout vaak één vijfde of zelfs één tiende is van de waarde van de coëfficiënt. We hebben dus te maken met zeer betrouwbare schattingen.

$J$ is het aantal waarnemingen dat voor de schattingen is gebruikt. $p^{2}$ is een aanduiding voor de verklaringswaarde van de gebruikte specificatie: bij $\rho^{2}$ $=1$ is de verklaring perfect, bij $\rho^{2}=0$ is deze nihil. De door ons uitgerekende waarden van $\rho^{2}$ zijn respectievelijk .94 en .98 . De verklaringswaarde van de door ons gebruikte specificaties is dus zeer hoog. 